\title{
Regional variation of the minimum wages in China
}

Chunbing Xing ${ }^{1,2^{*}}$ and Jianwei $X u^{1}$

\author{
* Correspondence: \\ xingchb@bnu.edu.cn \\ ${ }^{1}$ Beijing Normal University, Beijing, \\ China \\ ${ }^{2}$ IZA, Bonn, Germany
}

\begin{abstract}
This paper analyzes the regional variation of minimum wage in China. We first introduce the institutional background of China's minimum-wage policy and then describe the regional variation of the minimum wages using detailed minimumwage data since the late 1990s. A large regional variation exists in the period studied, and the regional variation has been declining since the late 1990s. Economic factors, including GDP, economic structure, and consumption level, are the main determinants for the large regional variation in the minimum wages. There is evidence suggesting that the regional variation is influenced by political factors, such as competition of local officials.

Jel codes: J3, E2

Keywords: Minimum wage, Regional variation, China
\end{abstract}

\section{Springer}

\section{Introduction}

Wages in China were set by the authority in the earlier economic regime of central planning, and no labor market existed. With the establishment of socialist market economy, the labor market has started to function (Chi et al. 2012). Employers have autonomy to hire and fire workers, and the workers have more freedom to choose employers. The wages are mainly determined by the labor market conditions. Meanwhile, wage inequality increases. In particular, the low wages of those disadvantaged workers (less educated, young workers, laid-off workers, rural-to-urban migrants) constitute a major contribution to the rising wage inequality (Xing and Li 2012).

The minimum-wage policy was supposed to serve several purposes including increasing the income of low-paid workers, guaranteeing living standard of their families, and reducing income inequality. The complication of the minimum-wage policy varies considerably across countries (Rani et al., 2013). Some countries set a uniform minimum wage for the whole country, while others set minimum wages for different regions, industries, or employment of different characteristics such as age, gender, and education levels. In China, the minimum wages vary across regions, and existing studies use variation of this dimension (as well as temporal variation) to identify the effect of minimum-wage policy on wages, employment, inequality, etc (see Fang and Lin 2014; Yang and Gunderson 2014). However, little is known about the factors that influence the regional variation of the minimum wages. This paper aims to describe the

(c) 2016 Xing and Xu. Open Access This article is distributed under the terms of the Creative Commons Attribution 4.0 International License (http://creativecommons.org/licenses/by/4.0/), which permits unrestricted use, distribution, and reproduction in any medium, provided you give appropriate credit to the original author(s) and the source, provide a link to the Creative Commons license, and indicate if changes were made. 
institutional background for the determination of regional minimum wages and to explore mechanisms behind this variation.

We first describe the procedure for the adjustment of local minimum wages, emphasizing China's decentralized feature and the incentives of the local government. Then, we describe the regional variations of the minimum wage using detailed minimumwage data. We find a large regional variation during the period studied. Meanwhile, most inequality measures we use suggest a decline in the regional variation especially after 2004. Third, we explain the regional variation in the minimum wages using citylevel variables collected from the city statistical yearbook. Economic development factors, including GDP, economic structure, and consumption level, are the main driving force for the large regional variation in minimum wages. Finally, there also is weak evidence suggesting that the regional variation is influenced by political factors, such as competition between officials of different locations.

This paper is organized as follows. Section 2 briefly summarizes the literature related to the determination of the minimum wage. Section 3 introduces the institutional background of the minimum-wage policy in China. Section 4 introduces the data and describes the regional variation in minimum wages and its trend. Section 5 uses econometric model to explore the factors that influence the regional variation of the minimum wage. Section 6 explores the variation in the time when new minimum wages were implemented. Section 7 discusses the implications of our results for reforming China's minimum-wage policy and concludes.

\section{Literature review}

Conceptually, minimum wage should be determined according to its goals, which vary considerably over time and across countries with different institutions. Such goals include poverty reduction (Stigler 1946; Sobel 1999), increasing the total income of minimum-wage workers (Sobel 1999), reducing inequality (Johnson and Browning 1983), and even industry upgrading, which is forcing firms to adopt more advanced labor saving techniques (Stigler 1946). Textbook economics show that unemployment increases if the minimum wage is set above the market equilibrium level. An optimal minimum-wage policy is determined by the trade-off between those goals and the adverse employment effect. That is why considerable amount of effort has been spent to estimate the unemployment effect of the minimum wage. Unfortunately, the literature has not reached a consensus regarding the employment effect of the policy (Card and Krueger 1995; Neumark and Wascher 2008).

In this context, minimum wages should be determined by factors related to living standard, labor cost, income distribution, and employment situations. Importantly, the minimum wage should be related to some economic parameters. For example, Sobel (1999) points out that the minimum wage should be set where the labor demand elasticity is unitary to maximize the total income of minimum-wage workers.

However, most research shows that the minimum wage is heavily influenced by political factors. Such factors include voting, interest group pressure, and partisan ideology. Flinn (2011), for example, documents the fierce political conflicts regarding whether the federal government should set minimum wages for each state. Sobel (1999) asks whether the adjustment of the minimum wage is influenced by political factors other than economic factors, and he finds that unions play an important role. Many other 
studies show that the passage of the minimum-wage legislation and its subsequent increases are mainly driven by interest group pressures (Silberman and Durden 1976; Kau and Rubin 1978; Bloch 1980, 1993; Seltzer 1995). Empirically, researchers looked at the relative power of some interest groups (the union vs. business ratio, for example, Sobel 1999; Johnson 2002), voting in congress elections, and ideological factors (Kau and Rubin 1978). But, these variables do not readily apply in China.

When minimum wages vary across regions as in China, the process is often decentralized, and the local governments play an important role. First, they have more autonomy to set the minimum wages according to local economic conditions. Second, minimum wages could be an instrument for them to manage local economy and to compete with other regions. On the one hand, higher minimum wage might be a signal of better economic performance that not only attracts quality workers but also enhances promotion probability of local officials. On the other hand, higher minimum wage increases labor cost and deters capital investment. When labor and capital are mobile across regions, this will be a real concern for local governments. They are forced to consider each other's behavior.

Political consideration influences not only the level of the minimum wages but also the effective date of the changes and the number and timing of the series of steps (Sobel 1999). In this paper, we will discuss how the timing of the minimum adjustment is related to the magnitude of its changes.

Thus, the paper is related to a growing literature that studies the promotion competition between local officials ( $\mathrm{Li}$ and Zhou 2005). Existing studies show that this competition (like a tournament model) plays an important role in China's economic growth. The basic story is as follows: Officials who are more capable of producing high GDP growth have higher probability of being promoted. This provides a strong incentive for local officials to take measures to boost the local economy. Guo et al. (2013) indicate that personal characteristics of the local officials have a significant effect on the local policies such as the supply of land for different uses. As the minimum-wage policy might influence the local economy in many ways (firm profits, firm's location choice, employment), it serves as a potential instrument of this competition.

\section{Institutional background of the minimum-wage policy in China}

China's minimum-wage policy came into shape in the early 1990s. In late 1993, the former Ministry of Labor issued Provisions of Minimum Wage, the first document on the minimum-wage policy. This policy did not have substantive effect because it is poorly implemented. In 2004, the Provisions of Minimum Wage was amended substantially by the Ministry of Human Resources and Social Security. The new provisions are different from the old version in the following aspects: (1) minimum wages are applicable to all enterprises including the town and village enterprises (TVEs), privately or individually owned enterprises, and non-profit organizations like schools and hospitals. (2) Hourly minimum wages was introduced into the system, which is applied to parttime employment. (3) The new regulation requires local governments to adjust the minimum wage at least once in every 2 years. (4) It requires the local government to publicize the minimum wages through public media. (5) The enforcement of the minimum-wage policy is strengthened. 
Under the new regulation, employers are more likely to abide the regulations as the punishment for the violation of this provision has increased significantly (it could be as high as five times of the wages detained). Meanwhile, the department of human resources and social security of the local government has the authority to inspect the enforcement of the minimum-wage regulations within its jurisdiction. Unions of different levels can monitor the implementation of the minimum wage, and they can demand enforcement and penalty if violation of the minimum-wage provisions was found.

Local governments play a dominant role in the process of adjusting minimum wages. The basic procedure is as follows: The department of human resources and social security at the provincial level (including province, autonomous regions, and municipalities administered directly by the central government) works out a minimum-wage schedule for negotiation. This schedule is made according to the guidance of the central government (the Ministry of Human Resources and Social Security), which is usually a guideline for calculating minimum wages taking into consideration various factors. These firstly include factors influencing the living standard of people in poverty such as urban consumer price index and the subsistence expenditure of the urban residents. As minimum wages above the equilibrium market wages will increase the labor cost of the employers and therefore reduce employment, employment situation should also be considered. Finally, the minimum wage should be adjusted according to whether it includes the social security fees and housing funds paid by the employees.

Economic development level varies a lot within a province, and the provincial government usually applies several minimum wages according to the economic development level of different regions. Usually, the provincial capital city has the highest minimum wage, while remote poor regions apply the lowest. Even for the provincial capital city, it may include some relatively poor counties in suburban areas, which may choose lower minimum wages.

This adjustment plan will then be negotiated between several parties, including the provincial government, provincial-level unions, association of entrepreneurs/enterprises, and chamber of commerce. The local government of the lower level can also influence the minimum-wage schedule. For example, a prefecture-level city may negotiate a lower level minimum wage (or simply choose a lower level of minimum wage) due to the concern that high minimum wages are harmful for local governments to attract investment and to create employment.

After reaching an agreement, the plan will often be submitted to the provincial executive meetings for discussion. The provincial executive meeting is usually convened by the governor or the vice-governor of a province. Thus, provincial leaders can also influence the minimum-wage policies, the influence depending on the relative power and preference of the leaders. In particular, the local officials need to compete for higher positions. The minimum-wage policy might be an instrument in the competition. First, minimum wage could be a direct measure for the welfare of the local residents, with higher minimum wages representing a higher economic development level and higher living standard. Thus, the local officials tend to set a higher minimum wage, a so-called keep-up-with-the-Joneses effect. On the other hand, a high minimum wage might be harmful for the economy by deterring investments and reducing employment because from the perspective of the employers, a region with lower minimum wage seems more attractive due to lower labor cost. But, there also are some local 
governments, who believe that higher minimum wage will help them attract skilled workers. ${ }^{1}$ Whether these incentives (mechanisms) exist and the extents they matter are subject to empirical investigation.

The minimum-wage policy determined by the provincial government will then be submitted to the Ministry of Human Resources and Social Security for approval. It should be ratified by the All-China Federation of Trade Unions and All-China Federation of Industry and Commerce. This minimum-wage adjustment policy should be publicized through the government gazette and at least one local newspaper within 7 days of approval.

The Minimum Wage Provisions issued in 2004 requires the local (provincial) government to adjust the minimum wages at least once in every 2 years but does not mandate the exact date of the adjustment. Local governments often choose different dates to announce the newly adjusted minimum-wage policy.

\section{Regional variation of minimum wage and its evolution}

We use several data sets in the following analysis. The minimum-wage data is collected from various websites as every province publishes them once new minimum wages are determined. When a province publishes the minimum-wage policy, it declares the minimum-wage levels applicable to various regions or it allows the local government to choose appropriate levels. Different from other studies, we use the most detailed (disaggregated) minimum-wage data. Second, we collect city-level information from the China City Statistical Yearbook, including the average wages for the urban workers, GDP growth rate, GDP per capita, employment, unemployment, and actually utilized foreign direct investment (FDI). We use this information to construct explanatory variables to explain regional minimum wages (see below in Section 5).

As the effective date of the new minimum wage is not necessarily at the beginning of a year, we average the minimum wage according to the months applicable within a year. In addition, in order to match our minimum-wage data with the city-level variables, we also calculated weighted average of the minimum wages using the employment of the region where the minimum wages are applicable, and the formula is as follows:

$$
\mathrm{MW}_{c t}=\frac{\sum_{j \in c} \mathrm{MW}_{j c t} * \text { employ }_{j c t}}{\sum_{j \in c} \mathrm{employ}_{j c t}}
$$

among which, $\mathrm{MW}_{j c t}$ is the minimum wage in county $j$ of city $c$ at time $t$ and employ jct $_{c t}$ is the employment of the same region at time $t$. Using a similar formula, we are able to calculate the minimum wage at the provincial level. Having detailed minimum-wage information has the advantage that we cannot only have different measures of the regional minimum wage (the highest level and lowest level of the minimum wages, in addition to the weighted average of the minimum wage) but also can describe the regional variation more fully. For example, we can calculate the regional variation of the minimum wage within a city or within a province.

Finally, in addition to the absolute value of the minimum wages, we also investigate the relative minimum-wage levels, which is the minimum wage divided by the average wage of all the workers in the region. The formula is as follows: 


$$
\mathrm{MW}_{c t}=\frac{\sum_{j \in c} \mathrm{MW}_{j c t} * \mathrm{employ}_{j c t} / \sum_{j \in c} \mathrm{employ}_{j c t}}{\mathrm{AW}_{c}}
$$

$\mathrm{AW}_{c t}$ is the average wage in city $c$ at time $t$, which can be obtained from the China City Statistical Yearbook. $\mathrm{MW}_{j c t}$ and employ ${ }_{j c t}$ are as previously defined.

Before describing the regional variation of the minimum wage, we investigate the trend of minimum wages at the national level. Figure 1 shows that the average minimum wage for the whole nation increased significantly between 2004 and 2010. However, the increase is slower than that of the wages for urban workers, and the ratio of minimum wage over average wages decreased significantly during this period.

To see the regional variation, Fig. 2a reports the average number of minimum wages applied within a province and such a number for the whole China in each year. The solid line in the figure shows that the number of minimum wages for a representative province decreased significantly. In 2004, an average province applied over five minimum wages, and by 2012, it has decreased to less than four. If we count minimum wages of different levels for China as a whole, the number increased in recent years. This seemingly contradictory phenomenon is caused by the fact that different provinces become less likely to have minimum wages of the same level than before.

Figure $2 \mathrm{~b}$ further reports another dimension of the regional variation for the minimum wages, namely the ratio of the highest over the lowest minimum wages (high-tolow or HL ratio) for each province and for China. Again, the regional gap appears to have decreased from the late 1990s. In around 2000, the ratio was 1.5 for an average province, and it decreased to 1.3 by 2012 . The same pattern is also observed for the whole country, with the ratio decreasing from 3.5 in around 2000 to 2.5 in 2012.

We also use two traditional inequality indices (Gini coefficient and the coefficient of variation) to investigate the trend in the regional variation of the minimum wages (see Fig. 2c). In calculating them, each county is treated as an observation, without

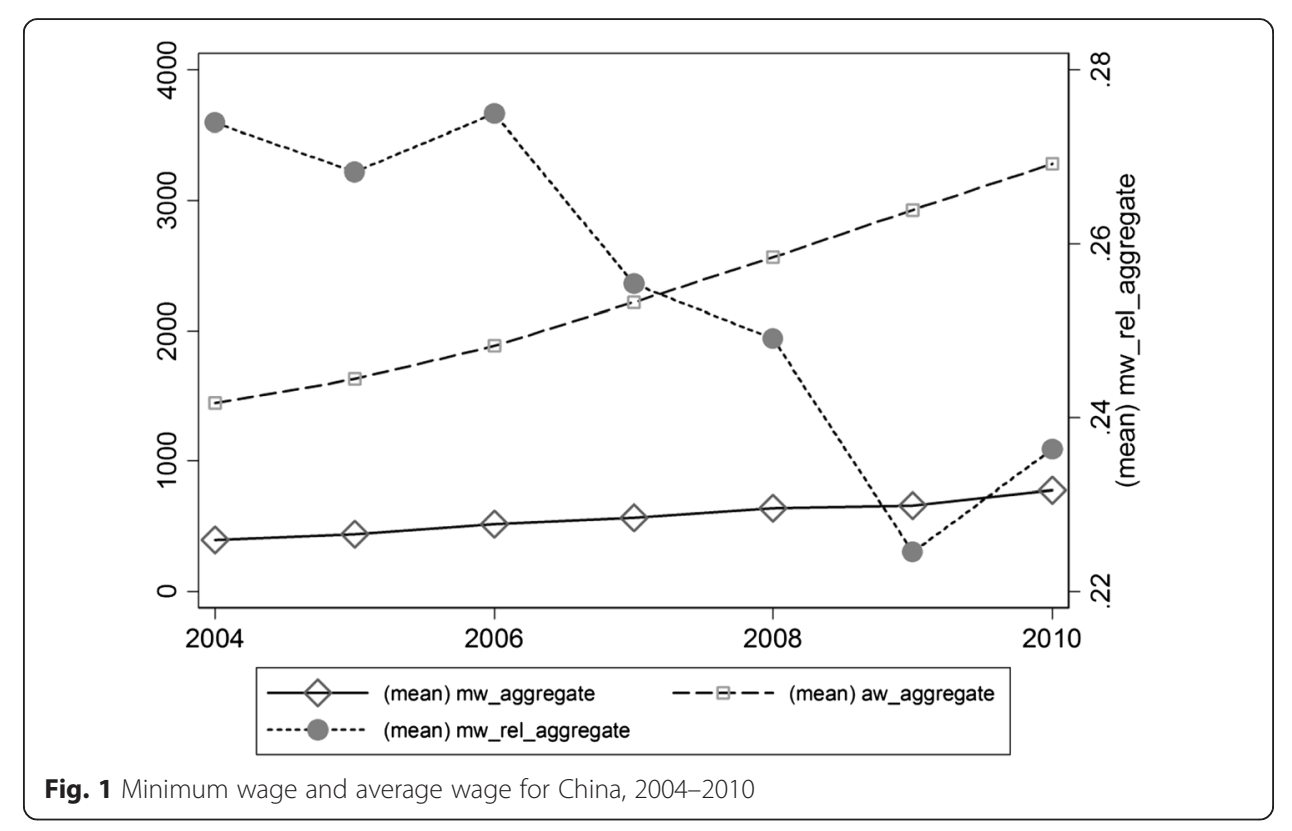



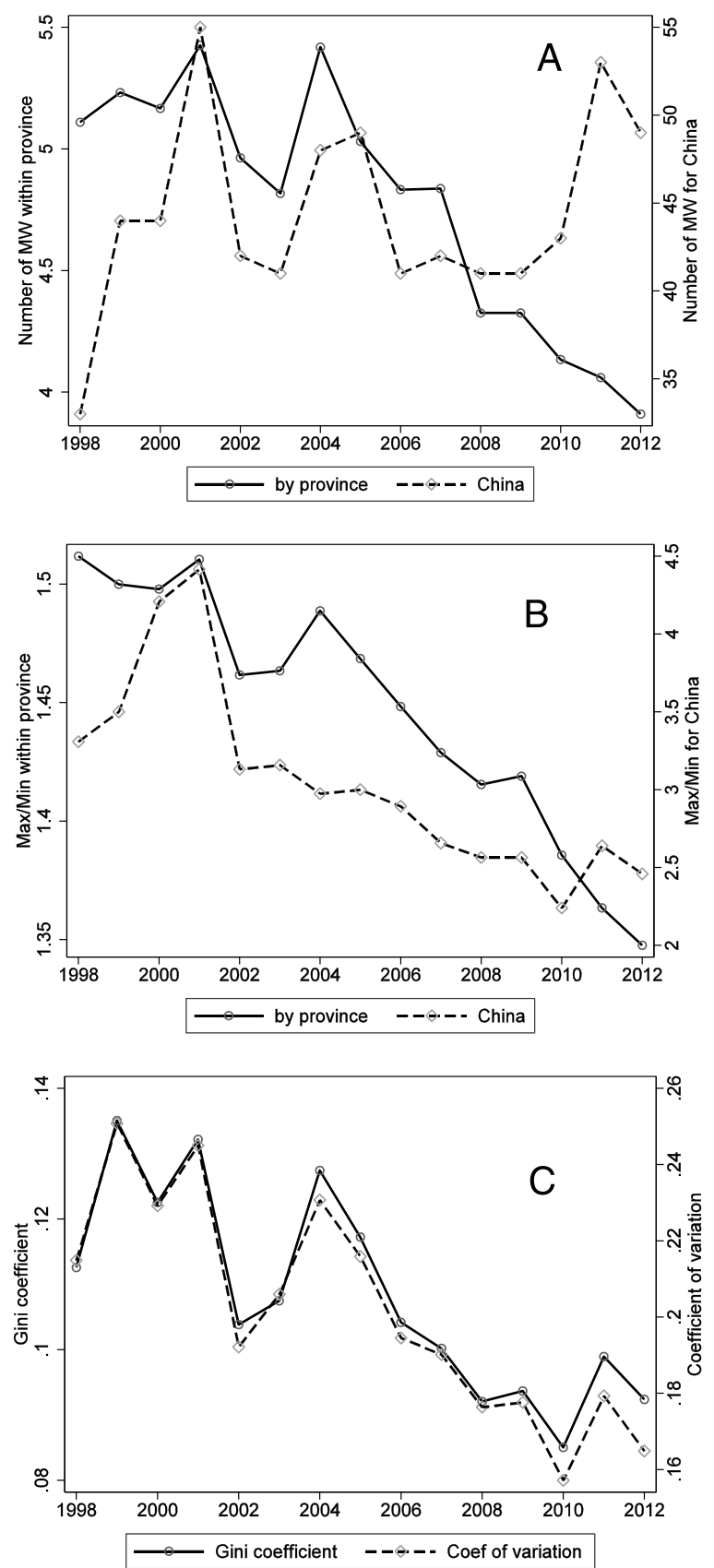

Fig. 2 Regional variation of minimum wages within a province and within China (a. Number of minimum wage levels; $\mathbf{b}$. The High-to-Low ratio of the minimum wages; $\mathbf{c}$. inequality in minimum wage levels.)

considering relevant population within that county. Both measures show that the regional variation has declined, especially after $2004 .^{2}$

There is large heterogeneity in terms of the regional variation within a province. Table 1 reports the regional gap of minimum wages within each province in 2004 and 2012. In 2004, the minimum wages were low in most provinces, ranging from 253 (Jiangxi province) to 603 (Shanghai) RMB. Guangdong province applied minimum wages of 14 levels: Shenzhen applied the highest minimum wage (607 RMB), while Heyuan applied the lowest (288 RMB), the high-to-low ratio reaching $2.07 .^{3}$ This is 
Table 1 Minimum wages by province, 2004 and 2012

\begin{tabular}{|c|c|c|c|c|c|c|c|c|c|c|}
\hline \multirow[b]{2}{*}{ Province } & \multicolumn{5}{|l|}{2004} & \multicolumn{5}{|l|}{2012} \\
\hline & Average & Max & Min & \# of $\mathrm{mw}$ & Max/min & Average & Max & Min & \# of mw & Max/min \\
\hline Anhui & 312 & 410 & 290 & 10 & 1.52 & 712 & 1010 & 680 & 7 & 1.49 \\
\hline Beijing & 495 & 495 & 495 & 1 & 1.00 & 1260 & 1260 & 1260 & 1 & 1.00 \\
\hline Fujian & 324 & 480 & 280 & 7 & 1.71 & 897 & 1200 & 830 & 4 & 1.45 \\
\hline Gansu & 304 & 340 & 300 & 3 & 1.13 & 839 & 980 & 860 & 4 & 1.14 \\
\hline Guangdong & 369 & 684 & 330 & 14 & 2.07 & 925 & 1500 & 850 & 6 & 1.76 \\
\hline Guangxi & 330 & 460 & 320 & 4 & 1.44 & 819 & 1000 & 690 & 4 & 1.45 \\
\hline Guizhou & 309 & 400 & 320 & 3 & 1.25 & 801 & 930 & 740 & 3 & 1.26 \\
\hline Hainan & 358 & 500 & 350 & 3 & 1.43 & 788 & 1050 & 900 & 3 & 1.17 \\
\hline Hebei & 376 & 520 & 420 & 3 & 1.24 & 1058 & 1320 & 1040 & 4 & 1.27 \\
\hline Henan & 257 & 380 & 240 & 3 & 1.58 & 913 & 1080 & 820 & 3 & 1.32 \\
\hline Heilongjiang & 288 & 390 & 235 & 7 & 1.66 & 677 & 1160 & 850 & 4 & 1.36 \\
\hline Hubei & 277 & 400 & 240 & 5 & 1.67 & 827 & 1100 & 750 & 3 & 1.47 \\
\hline Hunan & 346 & 460 & 320 & 7 & 1.44 & 885 & 1160 & 870 & 4 & 1.33 \\
\hline Jilin & 323 & 360 & 300 & 3 & 1.20 & 919 & 1150 & 950 & 3 & 1.21 \\
\hline Jiangsu & 425 & 620 & 360 & 4 & 1.72 & 997 & 1320 & 950 & 3 & 1.39 \\
\hline Jiangxi & 253 & 360 & 270 & 4 & 1.33 & 715 & 870 & 610 & 5 & 1.43 \\
\hline Liaoning & 288 & 440 & 230 & 11 & 1.91 & 891 & 1100 & 780 & 5 & 1.41 \\
\hline Inner Mongolia & 344 & 420 & 380 & 3 & 1.11 & 962 & 1200 & 900 & 4 & 1.33 \\
\hline Ningxia & 342 & 380 & 320 & 3 & 1.19 & 960 & 1100 & 950 & 3 & 1.16 \\
\hline Qinghai & 264 & 370 & 330 & 4 & 1.12 & 924 & 1070 & 1050 & 3 & 1.02 \\
\hline Shandong & 356 & 410 & 290 & 5 & 1.41 & 1044 & 1240 & 950 & 3 & 1.31 \\
\hline Shanxi & 355 & 520 & 400 & 4 & 1.30 & 906 & 1125 & 855 & 4 & 1.32 \\
\hline Shaanxi & 275 & 320 & 245 & 4 & 1.31 & 881 & 1000 & 790 & 4 & 1.27 \\
\hline Shanghai & 603 & 635 & 635 & 1 & 1.00 & 1408 & 1450 & 1450 & 1 & 1.00 \\
\hline Sichuan & 270 & 450 & 230 & 7 & 1.96 & 891 & 1050 & 800 & 4 & 1.31 \\
\hline Tianjin & 501 & 530 & 510 & 2 & 1.04 & 1273 & 1310 & 1310 & 1 & 1.00 \\
\hline Tibet & 306 & 495 & 445 & 3 & 1.11 & 1171 & 1200 & 1150 & 2 & 1.04 \\
\hline Xinjiang & 325 & 480 & 300 & 9 & 1.60 & 949 & 1340 & 980 & 4 & 1.37 \\
\hline Yunnan & 304 & 470 & 350 & 3 & 1.34 & 949 & 1100 & 830 & 3 & 1.33 \\
\hline Zhejiang & 491 & 620 & 440 & 4 & 1.41 & 1170 & 1310 & 950 & 4 & 1.38 \\
\hline Chongqing & 342 & 400 & 330 & 4 & 1.21 & 931 & 1050 & 950 & 2 & 1.11 \\
\hline Average & & & & 4.81 & 1.40 & & & & 3.48 & 1.28 \\
\hline
\end{tabular}

consistent with the fact that the development within Guangdong is regionally unbalanced, with Shenzhen and Guangzhou having high economic growth while other inner cities grew slower. Provinces that applied minimum wages of 10 levels also include Anhui and Liaoning. In 2012, no province had over ten minimum wages. Guangdong applied six, following Anhui (seven). The high-to-low ratio also decreased for over two thirds of the provinces.

We run regressions of the number of minimum wages and the HL ratio within a province on provincial characteristics to explore associated factors, and the results are reported in Table 2. Panel A of Table 2 shows that both measures are positively associated with provincial population, especially in more recent years (2000-2007); they are 
Table 2 Explaining the number of minimum-wage levels and the high/low ratio within a province

\begin{tabular}{|c|c|c|c|c|c|c|}
\hline & \multicolumn{3}{|c|}{ Number of mw } & \multicolumn{3}{|l|}{ Max/min } \\
\hline & (1) & (2) & (3) & $\overline{(4)}$ & (5) & (6) \\
\hline & 1995-2007 & 1995-1999 & $2000-2007$ & 1995-2007 & 1995-1999 & 2000-2007 \\
\hline \multirow[t]{2}{*}{ Ln(population) } & $0.810^{c}$ & 0.226 & $1.043^{c}$ & $0.121^{c}$ & 0.0587 & $0.150^{c}$ \\
\hline & $(0.223)$ & $(0.396)$ & $(0.310)$ & $(0.0229)$ & $(0.0422)$ & $(0.0295)$ \\
\hline \multirow[t]{2}{*}{ Ln(GDP per capita) } & $1.276^{\mathrm{a}}$ & $2.231^{a}$ & 0.783 & 0.0782 & 0.169 & -0.00300 \\
\hline & $(0.712)$ & $(1.158)$ & $(0.966)$ & $(0.0730)$ & $(0.124)$ & $(0.0917)$ \\
\hline \multirow[t]{2}{*}{ Tertiary sector share in GDP } & $-5.765^{\mathrm{a}}$ & -3.995 & $-6.981^{\mathrm{a}}$ & -0.291 & 0.471 & $-0.817^{\mathrm{b}}$ \\
\hline & $(2.995)$ & $(5.997)$ & (3.678) & $(0.307)$ & $(0.640)$ & $(0.349)$ \\
\hline \multirow[t]{2}{*}{ Urban-rural income gap } & $0.759^{b}$ & $1.574^{c}$ & 0.369 & $0.0574^{\mathrm{a}}$ & $0.145^{\mathrm{b}}$ & 0.000945 \\
\hline & $(0.327)$ & $(0.546)$ & $(0.426)$ & $(0.0335)$ & $(0.0583)$ & $(0.0405)$ \\
\hline \multirow[t]{2}{*}{ Ln(average wage) } & $-2.437^{\mathrm{a}}$ & -3.066 & -1.463 & $-0.419^{c}$ & $-0.743^{c}$ & -0.121 \\
\hline & $(1.292)$ & $(2.114)$ & $(1.752)$ & $(0.132)$ & $(0.226)$ & $(0.166)$ \\
\hline \multirow[t]{2}{*}{ Trade share in GDP } & $1.218^{\mathrm{a}}$ & 2.159 & 0.986 & $0.327^{c}$ & $0.719^{c}$ & $0.202^{c}$ \\
\hline & $(0.656)$ & $(1.335)$ & $(0.769)$ & $(0.0673)$ & $(0.143)$ & $(0.0730)$ \\
\hline \multirow[t]{2}{*}{ Fiscal expenditure in GDP } & 2.618 & -1.328 & 3.573 & $0.503^{\mathrm{a}}$ & 0.689 & 0.496 \\
\hline & $(2.526)$ & $(6.004)$ & $(3.171)$ & $(0.259)$ & $(0.641)$ & $(0.301)$ \\
\hline \multirow[t]{2}{*}{ Fixed investment/GDP } & -1.542 & $-8.145^{b}$ & -0.750 & -0.215 & $-0.988^{b}$ & -0.203 \\
\hline & $(1.511)$ & $(3.564)$ & $(1.951)$ & $(0.155)$ & $(0.381)$ & $(0.185)$ \\
\hline$N$ & 365 & 141 & 224 & 365 & 141 & 224 \\
\hline Adj. $R^{2}$ & 0.146 & 0.136 & 0.153 & 0.284 & 0.299 & 0.349 \\
\hline
\end{tabular}

Standard errors in parentheses; ${ }^{a},{ }^{b}$, and ${ }^{c}$ represent significance levels of 10,5 , and $1 \%$, respectively

also positively associated with rural-urban income gap and the degree of openness (measured as the ratio of trade volume over GDP), but the correlations are sometimes insignificant and the correlation is stronger in earlier years (1995-1999). These patterns suggest that both the number of minimum-wage levels and the HL ratios reflect the regional imbalance (heterogeneity) within a province. Other factors also influence these two measures: GDP per capita is generally positively correlated with the withinprovince variation; the share of tertiary industry is negatively correlated with the within-province variation. In the model explaining the number of minimum-wage levels, the adjusted $R^{2}$ is around $15 \%$, suggesting that there are many other factors in play as well. The model is more successful in explaining the HL ratio, but still, the adjusted $R^{2}$ is only around $30 \%$.

It is also important to keep in mind that we are trying to explain the within-province variation, which is only a portion of the overall regional variation. In Table 3, we decompose the variance in the minimum wage into three parts: variance due to provincial differences, city-level differences within a province, and county-level differences within a city. If we look at the minimum wage in absolute terms, over $60 \%$ of the variation comes from provincial-level difference and $31 \%$ from city-level difference. Variation within a city is less important, accounting for less than $10 \%$. This is consistent with the fact that the minimum wages are determined at the provincial level.

We next consider the relative level of minimum wages, which is the ratio of minimum wage to average wage of this region. The ratio is calculated at the city level: we first calculate the average minimum wage for each city and divided it by the average 
wage of the same city. We calculate the statistics of the relative minimum-wage distributions for each province, which are reported in Table 4. The mean relative minimum wage varies a lot across provinces, ranging from $40 \%$ (like in Shanxi, Hebei) to $20 \%$ (Beijing) in 2004. The range is around 18-33\% in 2010.

Similar to the statistics for the absolute value, there is a large variation for the relative minimum wage within a province. Take Anhui province, for example. In 2004, the minimum wage was only $19.5 \%$ of the average wage in the region with the lowest relative minimum wage, while the highest ratio was $37 \%$. The within-province variations of the relative minimum wages also vary considerably across provinces. The province with the largest standard deviation of the relative minimum wage was Hubei in 2004, which is 0.10. Beijing, Tianjin, Shanghai, and Chongqing had the lowest standard deviation, zero. Around two thirds of the provinces experienced decreases in the regional variation between 2004 and 2010.

\section{The determinants of minimum wage}

What determines minimum wages of different regions? This section explores this question by running regressions of the minimum wages on candidate explanatory variables. Our goal is to explain the regional variation rather than to identify the causal relationship. Therefore, we do not use panel data models. However, we control for city-fixed effects in some regressions later.

In a decentralized system, local economic conditions play an important role in determining the minimum wages. We use GDP per capita (in log) to capture the local economic development level and use GDP growth rate to capture the dynamics of the economy. Although GDP level is expected to be positively correlated with the minimum wage, its growth rate is not. For example, a growth-rate-seeking leader may purposely set a low minimum wage to attract investment. The share of the tertiary sector in GDP reflects the structure of the local economy, and a more advanced economy usually has a higher share of the tertiary sector and also has a higher minimum wage. However, the tertiary sector includes many sub-sectors that are of quite different nature. Therefore, we also control for the share of the service sector in GDP. As the tertiary share and the service share contain different information, we consider both in the regression.

Because the unemployment effect is a main concern of minimum-wage setting, we consider employment rate, which is calculated as the share of the employed in the total working-age population. As both working-age population and the employment could be endogenously determined, minimum wage is not necessarily positively correlated with employment rate. For example, the population may become larger in a high minimum-wage region while the employment remains unchanged (or even declines), causing a negative relationship between employment rate and minimum wage (Harris

Table 3 Decomposing the regional variation of minimum wages

\begin{tabular}{llll}
\hline & $\begin{array}{l}\text { Variation across a } \\
\text { province (\%) }\end{array}$ & $\begin{array}{l}\text { City variation within a } \\
\text { province (\%) }\end{array}$ & $\begin{array}{l}\text { County variation } \\
\text { within a city (\%) }\end{array}$ \\
\hline Minimum wage & 60.40 & 30.75 & 8.86 \\
Average wage & 39.23 & 60.77 & 0.00 \\
\hline
\end{tabular}


and Todaro 1970). Another measure we consider is the number of enterprises per capita, which is more related to employment opportunities.

Private employment share captures the importance of the private sector, which may reflect the relative power of the employees/employers in the private sector. FDI share reflects the importance of foreign investment in the economy. Fiscal expenditure reflects the relative size of the government, and it is related to the employment of employees in the public service sector. Finally, while the local GDP reflects more of the general economic development, local consumption level is more related to the living standard of workers. We consider consumption per capita both in rural and urban areas because minimum wage often varies considerably within a city. In regions with the lowest minimum wage, rural consumption level may be more appropriate for

Table 4 Minimum wages relative to average wages by province, 2004 and 2010

\begin{tabular}{|c|c|c|c|c|c|c|c|c|}
\hline & \multicolumn{4}{|l|}{2004} & \multicolumn{4}{|l|}{2010} \\
\hline & Min & Max & Mean & S.D. & Min & Max & Mean & S.D. \\
\hline Anhui & 0.195 & 0.368 & 0.292 & 0.044 & 0.161 & 0.264 & 0.207 & 0.028 \\
\hline Beijing & 0.198 & 0.198 & 0.198 & 0.000 & 0.173 & 0.173 & 0.173 & 0.000 \\
\hline Fujian & 0.208 & 0.311 & 0.245 & 0.032 & 0.212 & 0.335 & 0.259 & 0.042 \\
\hline Gansu & 0.183 & 0.459 & 0.303 & 0.077 & 0.184 & 0.370 & 0.283 & 0.067 \\
\hline Guangdong & 0.197 & 0.420 & 0.286 & 0.067 & 0.205 & 0.344 & 0.260 & 0.040 \\
\hline Guangxi & 0.261 & 0.373 & 0.320 & 0.038 & 0.216 & 0.502 & 0.274 & 0.073 \\
\hline Guizhou & 0.307 & 0.342 & 0.324 & 0.016 & 0.263 & 0.303 & 0.280 & 0.017 \\
\hline Hainan & 0.341 & 0.411 & 0.376 & 0.050 & 0.291 & 0.298 & 0.295 & 0.005 \\
\hline Hebei & 0.310 & 0.439 & 0.375 & 0.037 & 0.234 & 0.298 & 0.262 & 0.022 \\
\hline Henan & 0.184 & 0.378 & 0.269 & 0.056 & 0.226 & 0.378 & 0.295 & 0.039 \\
\hline Heilongjiang & 0.186 & 0.529 & 0.314 & 0.091 & 0.215 & 0.458 & 0.289 & 0.078 \\
\hline Hubei & 0.171 & 0.589 & 0.310 & 0.100 & 0.244 & 0.651 & 0.332 & 0.109 \\
\hline Hunan & 0.257 & 0.473 & 0.315 & 0.058 & 0.201 & 0.331 & 0.268 & 0.039 \\
\hline Jilin & 0.204 & 0.441 & 0.326 & 0.082 & 0.253 & 0.411 & 0.319 & 0.057 \\
\hline Jiangsu & 0.220 & 0.359 & 0.299 & 0.040 & 0.199 & 0.245 & 0.222 & 0.015 \\
\hline Jiangxi & 0.228 & 0.433 & 0.303 & 0.053 & 0.213 & 0.303 & 0.255 & 0.030 \\
\hline Liaoning & 0.177 & 0.351 & 0.234 & 0.047 & 0.172 & 0.335 & 0.261 & 0.040 \\
\hline Inner Mongolia & 0.268 & 0.422 & 0.347 & 0.058 & 0.196 & 0.350 & 0.268 & 0.045 \\
\hline Ningxia & 0.239 & 0.329 & 0.293 & 0.036 & 0.177 & 0.250 & 0.222 & 0.029 \\
\hline Qinghai & 0.238 & 0.238 & 0.238 & 0.000 & 0.269 & 0.269 & 0.269 & 0.000 \\
\hline Shandong & 0.158 & 0.365 & 0.289 & 0.048 & 0.217 & 0.350 & 0.256 & 0.031 \\
\hline Shanxi & 0.344 & 0.554 & 0.412 & 0.063 & 0.184 & 0.355 & 0.272 & 0.049 \\
\hline Shaanxi & 0.220 & 0.300 & 0.272 & 0.024 & 0.196 & 0.294 & 0.238 & 0.027 \\
\hline Shanghai & 0.254 & 0.254 & 0.254 & 0.000 & 0.187 & 0.187 & 0.187 & 0.000 \\
\hline Sichuan & 0.185 & 0.338 & 0.244 & 0.039 & 0.195 & 0.358 & 0.281 & 0.038 \\
\hline Tianjin & 0.283 & 0.283 & 0.283 & 0.000 & 0.208 & 0.208 & 0.208 & 0.000 \\
\hline Xinjiang & 0.249 & 0.281 & 0.265 & 0.023 & 0.233 & 0.299 & 0.266 & 0.046 \\
\hline Yunnan & 0.210 & 0.437 & 0.307 & 0.068 & 0.203 & 0.355 & 0.256 & 0.051 \\
\hline Zhejiang & 0.221 & 0.320 & 0.275 & 0.032 & 0.220 & 0.355 & 0.279 & 0.039 \\
\hline Chongqing & 0.277 & 0.277 & 0.277 & 0.000 & 0.186 & 0.186 & 0.186 & 0.000 \\
\hline
\end{tabular}


calculating the minimum wage. In richer regions, however, urban consumption may be more appropriate.

As we are mainly using the variables of the city-level characteristics from the city statistical yearbook, we have several choices for the dependent variables to be used in the regression. First, we use the log of the highest minimum wage within a city, and the results are reported in columns $1-4$ in Table 5 .

Economic development seems to be the major factor that influences the minimum wage. In particular, GDP per capita, economic structure (share of the tertiary industry in GDP), and the per capita number of enterprises are strong predictors for the citylevel minimum wages, and these variables are positively correlated with the minimum wage at the significance level of $1 \%$. The amount of FDI (relative to GDP) is also positively correlated with the minimum wage but only marginally significant at the $10 \%$ level. In the second column, we control for the consumption level in both rural and urban areas within the city. This decreases the number of observations of city-year

Table $\mathbf{5}$ The determinants of the minimum wages at the city level, OLS

\begin{tabular}{|c|c|c|c|c|c|c|c|c|}
\hline & \multicolumn{8}{|c|}{ Dependent variable $=$} \\
\hline & \multicolumn{4}{|c|}{ Log(highest minimum wage within a city) } & \multicolumn{4}{|c|}{ Log(lowest minimum wage within a city) } \\
\hline & (1) & (2) & (3) & (4) & (5) & (6) & (7) & (8) \\
\hline \multirow[t]{2}{*}{ Ln(GDP per capita) } & $0.138^{c}$ & $0.103^{c}$ & $0.0389^{c}$ & 0.00738 & $0.128^{c}$ & $0.0711^{\mathrm{b}}$ & 0.0147 & -0.00956 \\
\hline & $(0.0239)$ & $(0.0328)$ & $(0.0138)$ & $(0.0216)$ & $(0.0229)$ & $(0.0311)$ & $(0.0205)$ & $(0.0298)$ \\
\hline \multirow[t]{2}{*}{ Employment rate } & -0.120 & -0.152 & 0.0292 & 0.0314 & -0.212 & -0.234 & 0.0365 & 0.0433 \\
\hline & $(0.162)$ & $(0.191)$ & $(0.0879)$ & $(0.174)$ & $(0.138)$ & $(0.168)$ & $(0.116)$ & $(0.229)$ \\
\hline \multirow[t]{2}{*}{ GDP growth rate } & $-0.221^{\mathrm{a}}$ & $-0.272^{b}$ & $-0.118^{a}$ & -0.00639 & -0.0390 & -0.174 & -0.0834 & 0.0120 \\
\hline & $(0.113)$ & $(0.115)$ & $(0.0675)$ & $(0.0832)$ & $(0.145)$ & $(0.163)$ & $(0.0950)$ & $(0.0920)$ \\
\hline \multirow[t]{2}{*}{ Tertiary sector share } & $0.280^{c}$ & $0.225^{c}$ & $0.0680^{\mathrm{b}}$ & -0.136 & $0.262^{c}$ & $0.181^{\mathrm{a}}$ & -0.0252 & -0.102 \\
\hline & $(0.0672)$ & $(0.0731)$ & $(0.0287)$ & $(0.0897)$ & $(0.0919)$ & $(0.0941)$ & $(0.0551)$ & $(0.117)$ \\
\hline \multirow{2}{*}{$\begin{array}{l}\text { Private employment } \\
\text { share }\end{array}$} & -0.137 & $-0.244^{b}$ & 0.0378 & -0.0249 & -0.105 & -0.196 & 0.0150 & 0.0259 \\
\hline & $(0.0934)$ & $(0.0922)$ & $(0.0459)$ & $(0.0580)$ & $(0.127)$ & $(0.120)$ & $(0.0629)$ & $(0.0535)$ \\
\hline \multirow[t]{2}{*}{ FDI share in GDP } & $0.515^{\mathrm{a}}$ & 0.394 & $0.401^{\mathrm{a}}$ & 0.166 & 0.429 & 0.173 & 0.361 & 0.299 \\
\hline & $(0.276)$ & $(0.316)$ & $(0.198)$ & $(0.124)$ & $(0.384)$ & $(0.400)$ & $(0.265)$ & $(0.190)$ \\
\hline \multirow{2}{*}{$\begin{array}{l}\text { Fiscal expenditure/ } \\
\text { GDP }\end{array}$} & -0.138 & -0.0891 & $-0.119^{a}$ & -0.0815 & 0.164 & 0.191 & $0.114^{\mathrm{a}}$ & -0.0433 \\
\hline & $(0.161)$ & $(0.154)$ & $(0.0656)$ & $(0.111)$ & $(0.174)$ & $(0.159)$ & $(0.0604)$ & $(0.133)$ \\
\hline \multirow[t]{2}{*}{ Service sector/GDP } & 0.867 & 0.663 & 0.0892 & -0.203 & 0.327 & 0.675 & -0.0169 & 0.178 \\
\hline & $(1.184)$ & $(1.073)$ & $(0.586)$ & $(0.684)$ & $(1.361)$ & $(1.334)$ & $(0.538)$ & $(0.844)$ \\
\hline \multirow{2}{*}{$\begin{array}{l}\text { Per capita number } \\
\text { of enterprises }\end{array}$} & $0.0159^{c}$ & $0.00916^{c}$ & $0.00186^{\mathrm{a}}$ & -0.00475 & $0.0200^{c}$ & $0.00944^{c}$ & 0.00323 & -0.00573 \\
\hline & $(0.00360)$ & $(0.00303)$ & $(0.00102)$ & $(0.00400)$ & $(0.00437)$ & $(0.00336)$ & $(0.00208)$ & $(0.00546)$ \\
\hline \multirow{2}{*}{$\begin{array}{l}\text { Ln(consumption } \\
\text { per capita)_rural }\end{array}$} & & 0.00858 & 0.0323 & 0.00291 & & $0.110^{b}$ & $0.0993^{c}$ & 0.0643 \\
\hline & & $(0.0434)$ & $(0.0194)$ & $(0.0370)$ & & $(0.0468)$ & $(0.0292)$ & $(0.0519)$ \\
\hline \multirow{2}{*}{$\begin{array}{l}\text { Ln(consumption } \\
\text { per capita)_urban }\end{array}$} & & $0.258^{c}$ & $0.217^{c}$ & 0.0491 & & $0.252^{c}$ & $0.151^{c}$ & 0.0407 \\
\hline & & $(0.0712)$ & $(0.0394)$ & $(0.0682)$ & & $(0.0796)$ & $(0.0361)$ & $(0.0773)$ \\
\hline Province dummies & No & No & Yes & No & No & No & Yes & No \\
\hline City dummies & No & No & No & Yes & No & No & No & Yes \\
\hline Year dummies & Yes & Yes & Yes & Yes & Yes & Yes & Yes & Yes \\
\hline N & 2042 & 1866 & 1866 & 1866 & 2042 & 1866 & 1866 & 1866 \\
\hline Adj. $R^{2}$ & 0.846 & 0.858 & 0.933 & 0.951 & 0.791 & 0.819 & 0.909 & 0.940 \\
\hline
\end{tabular}

Standard errors in parentheses; ${ }^{a},{ }^{b}$, and ${ }^{c}$ represent significance levels of 10,5 , and $1 \%$, respectively 
from 2042 to 1866, but the pattern remains unchanged. The urban consumption level is highly significant. Column 3 controls for provincial dummies, which reduces the magnitude and the significance level of most variables. One major change is that the coefficient on the share of employment in private sectors becomes positive and insignificant rather than being significantly negative. Column 4 further controls for city dummies. Unsurprisingly, most of the coefficients become insignificant.

In columns 5-8, we consider another measure: $\log$ of the lowest minimum wage within a city. Without controlling for province dummies, the results are similar to those in columns $1-2$, but the effects of those proxy variables for economic development are smaller in magnitude. Another difference is that the lowest minimum wage within a city is positively correlated with the consumption level of the rural areas.

The adjusted $R^{2}$ in Table 5 suggests that the ordinary least squares (OLS) regressions are fairly successful in explaining the variation of the minimum wages. The explanatory power of the model is $80-85 \%$ without controlling for regional dummies, and it reaches over $90 \%$ when provincial dummies are controlled for. The marginal gain in the explanatory power is low if we substitute provincial dummies with city dummies, consistent with the fact that province-level difference constitutes the major proportion of the regional variation.

As we include year dummies in our regressions, and the minimum wage increases significantly, it is possible that the year dummies play a major role in explaining the minimum wage. We next run regressions for each year, and without losing important information, we report the results for 2003 and 2009 in Table 6. Column 1 reports the results for 2003. The listed variables altogether can explain half of the variation across cities. However, only two variables (GDP per capita and consumption per capita for urban residents) are significant at the $5 \%$ level. Controlling for provincial dummies increases the explanatory power by nearly $40 \%$ from 0.513 to 0.881 (see column 2). If we use the lowest minimum wage within a city as the dependent variable (columns 3-4), GDP per capita becomes less important both in the magnitude and the significance level of its coefficient. The consumption in rural areas becomes significant, regardless of whether we control for provincial dummies. Again, city-level characteristics are not enough to capture relevant differences at the province level.

In 2009, the explaining power of these variables reaches $60 \%$ when the highest minimum wage within a city is used as the dependent variable. Controlling for province dummies increases the $R^{2}$ to 0.853 . It suggests that province-level differences become less important or the differences are highly correlated with the city-level characteristics.

Some new patterns emerge as we run regressions for each year. For example, GDP growth rate turns out to be negatively associated with the minimum wage. One explanation for this correlation is that a lower minimum wage is beneficial for GDP growth conditional on the economic development level.

Next, we consider the relative minimum wage. We have two alternative dependent variables: the ratio of the highest and the lowest minimum wage within a city to the average wage of that city. The results of using these two measures are similar to each other (see Table 7). Several factors that are positively correlated with the absolute value of the minimum wage turn to be negatively correlated with the relative minimum wage, including the GDP per capita and the per capita consumption of the urban residents. This suggests that the high GDP region have higher average wage, which might be influenced more by the high-income individuals. The fiscal expenditure share in GDP is 
Table 6 The determinants of minimum wages in 2003 and 2009, OLS

\begin{tabular}{|c|c|c|c|c|c|c|c|c|}
\hline & 2003 & & & & 2009 & & & \\
\hline & Max & Max & Min & Min & Max & Max & Min & Min \\
\hline & (1) & (2) & (3) & (4) & (5) & (6) & (7) & (8) \\
\hline Ln(GDP per capita) & $0.109^{b}$ & $0.0494^{b}$ & $0.0818^{\mathrm{a}}$ & 0.0230 & $0.115^{c}$ & $0.0502^{b}$ & $0.0802^{\mathrm{b}}$ & 0.0307 \\
\hline & $(0.0409)$ & $(0.0209)$ & $(0.0479)$ & $(0.0239)$ & $(0.0287)$ & $(0.0183)$ & $(0.0297)$ & $(0.0217)$ \\
\hline Employment rate & $-0.484^{a}$ & -0.203 & $-0.612^{a}$ & -0.141 & 0.0778 & 0.140 & 0.193 & 0.167 \\
\hline & $(0.274)$ & $(0.169)$ & $(0.318)$ & $(0.124)$ & $(0.177)$ & $(0.0876)$ & (0.199) & $(0.142)$ \\
\hline GDP growth rate & -0.448 & $-0.232^{\mathrm{a}}$ & -0.260 & -0.00420 & $-0.666^{c}$ & $-0.221^{c}$ & $-0.570^{b}$ & $-0.318^{a}$ \\
\hline & $(0.322)$ & $(0.129)$ & $(0.352)$ & $(0.133)$ & $(0.197)$ & $(0.0708)$ & $(0.220)$ & $(0.183)$ \\
\hline Tertiary sector share & 0.0458 & -0.00792 & 0.0403 & -0.0464 & $0.367^{c}$ & $0.155^{c}$ & $0.324^{b}$ & 0.0729 \\
\hline & $(0.0981)$ & $(0.0582)$ & $(0.135)$ & $(0.0486)$ & $(0.0948)$ & $(0.0558)$ & $(0.126)$ & $(0.105)$ \\
\hline Private employment & -0.104 & 0.0834 & -0.260 & $-0.209^{b}$ & $-0.278^{b}$ & -0.0547 & -0.134 & 0.0402 \\
\hline & $(0.272)$ & $(0.132)$ & $(0.341)$ & $(0.0867)$ & $(0.109)$ & $(0.0688)$ & $(0.135)$ & $(0.0923)$ \\
\hline FDI share in GDP & 0.524 & $0.656^{c}$ & 0.330 & $0.700^{c}$ & -0.266 & 0.113 & $-0.818^{a}$ & -0.0560 \\
\hline & $(0.387)$ & $(0.206)$ & $(0.415)$ & $(0.234)$ & $(0.383)$ & $(0.205)$ & $(0.415)$ & $(0.327)$ \\
\hline Fiscal expenditure/GDP & -0.197 & -0.154 & 0.349 & 0.133 & -0.0715 & -0.0678 & 0.130 & 0.0892 \\
\hline & $(0.314)$ & $(0.144)$ & $(0.313)$ & $(0.114)$ & $(0.104)$ & $(0.0940)$ & $(0.0990)$ & $(0.0873)$ \\
\hline Service sector/GDP & 0.612 & 0.811 & -0.500 & 0.737 & 0.599 & -0.362 & -0.501 & -0.768 \\
\hline & $(2.133)$ & $(0.809)$ & $(2.090)$ & $(0.597)$ & $(0.806)$ & $(0.799)$ & $(1.350)$ & $(1.056)$ \\
\hline of & 0.0109 & 0.00512 & 0.00890 & $0.00940^{\mathrm{b}}$ & $0.0101^{c}$ & $0.00331^{\mathrm{b}}$ & $0.0108^{b}$ & $0.00490^{a}$ \\
\hline & $(0.00869)$ & $(0.00405)$ & $(0.00884)$ & $(0.00454)$ & $(0.00345)$ & $(0.00142)$ & $(0.00391)$ & $(0.00264)$ \\
\hline per & 0.0135 & -0.00786 & $0.119^{b}$ & $0.103^{b}$ & 0.00467 & 0.0415 & $0.100^{a}$ & $0.0944^{b}$ \\
\hline & $(0.0429)$ & $(0.0303)$ & $(0.0519)$ & $(0.0437)$ & $(0.0428)$ & $(0.0248)$ & $(0.0529)$ & $(0.0381)$ \\
\hline isumption per & $0.245^{b}$ & $0.192^{c}$ & $0.293^{b}$ & 0.0563 & 0.110 & $0.157^{c}$ & 0.0690 & 0.0572 \\
\hline & $(0.109)$ & $(0.0602)$ & $(0.124)$ & $(0.0607)$ & $(0.0736)$ & $(0.0381)$ & $(0.0869)$ & $(0.0488)$ \\
\hline Province dummies & No & Yes & No & Yes & No & Yes & No & Yes \\
\hline N & 240 & 240 & 240 & 240 & 262 & 262 & 262 & 262 \\
\hline Adj. $R^{2}$ & 0.513 & 0.881 & 0.479 & 0.899 & 0.591 & 0.853 & 0.460 & 0.763 \\
\hline
\end{tabular}

Standard errors in parentheses; ${ }^{a}{ }^{b}$, and ${ }^{c}$ represent significance levels of 10,5 , and 1 , respectively

insignificant in explaining the absolute minimum wage (see Tables 5 and 6), but it turns negatively correlated with the relative minimum wage in Table 7 . The relative number of the scaled enterprises and the share of the service sector in GDP are positively correlated with the relative minimum wage. These patterns largely remain when we run regressions for separate years (see Table 8).

It is worth mentioning that we are less successful in explaining the relative minimum wage than in explaining the absolute value of the minimum wage in terms of the adjusted $R^{2}$ in the OLS regressions. For example, the adjusted $R^{2}$ is only around $10 \%$ in the regression for 2009 when the province dummies are not controlled for. Even with the province dummies being controlled for, the explaining power is only around $40-45 \%$. However, although many studies focus on the relative levels of the minimum wages, it is the absolute values that are determined by the tripartite negotiation process.

\section{The time to adjust the minimum wages}

The new provisions issued in 2004 require the local governments to adjust the minimum wage at least once in every 2 years. The local governments decide when to do so. 
Table $\mathbf{7}$ The determinants of the relative minimum wages, OLS

\begin{tabular}{|c|c|c|c|c|c|c|c|c|}
\hline & \multicolumn{8}{|c|}{ Dependent variable $=$} \\
\hline & \multicolumn{4}{|c|}{ Log(highest minimum wage within a city/average wage) } & \multicolumn{4}{|c|}{ Log(highest minimum wage within a city/average wage) } \\
\hline & $(1)$ & $(2)$ & (3) & (4) & $(5)$ & (6) & (7) & (8) \\
\hline \multirow[t]{2}{*}{ Ln(GDP per capita) } & $-0.00458^{c}$ & -0.00126 & $-0.00324^{c}$ & -0.000811 & $-0.00447^{c}$ & $-0.00168^{\mathrm{a}}$ & $-0.00336^{c}$ & -0.00111 \\
\hline & $(0.000465)$ & $(0.000787)$ & $(0.000687)$ & $(0.000875)$ & $(0.000421)$ & $(0.000944)$ & $(0.000606)$ & $(0.000941)$ \\
\hline \multirow[t]{2}{*}{ Employment rate } & 0.00127 & 0.0118 & -0.00278 & 0.00690 & 0.00106 & $0.0143^{\mathrm{a}}$ & -0.00144 & 0.00712 \\
\hline & $(0.00485)$ & $(0.00890)$ & $(0.00605)$ & $(0.0115)$ & $(0.00396)$ & $(0.00805)$ & $(0.00523)$ & $(0.0109)$ \\
\hline \multirow[t]{2}{*}{ GDP growth rate } & -0.00330 & -0.00552 & -0.00269 & -0.00405 & -0.00269 & -0.00489 & -0.00189 & -0.00362 \\
\hline & $(0.00449)$ & $(0.00359)$ & $(0.00446)$ & $(0.00378)$ & $(0.00414)$ & $(0.00329)$ & $(0.00405)$ & $(0.00342)$ \\
\hline \multirow[t]{2}{*}{ Tertiary sector share } & -0.00146 & -0.00446 & -0.00133 & -0.00368 & -0.00274 & -0.00268 & -0.00268 & -0.00202 \\
\hline & $(0.00193)$ & $(0.00322)$ & $(0.00196)$ & $(0.00342)$ & $(0.00195)$ & $(0.00350)$ & $(0.00194)$ & $(0.00356)$ \\
\hline \multirow[t]{2}{*}{ Private employment share } & -0.00199 & -0.00185 & -0.000602 & -0.00271 & $-0.00303^{\mathrm{a}}$ & -0.00114 & -0.00124 & -0.00163 \\
\hline & $(0.00178)$ & $(0.00280)$ & $(0.00187)$ & $(0.00362)$ & $(0.00169)$ & $(0.00240)$ & $(0.00195)$ & $(0.00298)$ \\
\hline \multirow[t]{2}{*}{ FDI share in GDP } & 0.00755 & 0.00387 & $0.00944^{\mathrm{a}}$ & -0.000662 & 0.00763 & 0.00721 & 0.00874 & 0.00220 \\
\hline & $(0.00470)$ & $(0.00523)$ & $(0.00513)$ & $(0.00547)$ & $(0.00516)$ & $(0.00553)$ & $(0.00567)$ & $(0.00585)$ \\
\hline \multirow[t]{2}{*}{ Fiscal expenditure/GDP } & $-0.0124^{c}$ & $-0.0113^{c}$ & $-0.0123^{c}$ & $-0.00783^{b}$ & $-0.00697^{\mathrm{a}}$ & $-0.00885^{\mathrm{C}}$ & $-0.00652^{\mathrm{a}}$ & $-0.00629^{a}$ \\
\hline & $(0.00377)$ & $(0.00326)$ & $(0.00338)$ & $(0.00357)$ & $(0.00379)$ & $(0.00310)$ & $(0.00325)$ & $(0.00338)$ \\
\hline \multirow[t]{2}{*}{ Service sector/GDP } & 0.0181 & 0.00900 & 0.0442 & 0.0190 & 0.0124 & 0.0000916 & 0.0342 & 0.0197 \\
\hline & $(0.0308)$ & $(0.0508)$ & $(0.0358)$ & $(0.0556)$ & $(0.0228)$ & $(0.0459)$ & $(0.0279)$ & $(0.0501)$ \\
\hline \multirow[t]{2}{*}{ Per capita number of enterprises } & $0.000289^{c}$ & 0.000206 & $0.000334^{c}$ & 0.000194 & $0.000303^{c}$ & 0.000162 & $0.000325^{c}$ & 0.000142 \\
\hline & $(0.0000956)$ & $(0.000146)$ & $(0.000105)$ & $(0.000177)$ & $(0.0000655)$ & $(0.000134)$ & $(0.0000677)$ & $(0.000170)$ \\
\hline \multirow[t]{2}{*}{ Ln(consumption per capita)_rural } & & & -0.000166 & -0.000602 & & & 0.00122 & 0.000700 \\
\hline & & & $(0.000949)$ & $(0.00203)$ & & & $(0.00101)$ & $(0.00215)$ \\
\hline \multirow[t]{2}{*}{ Ln(consumption per capita)_urban } & & & $-0.00456^{b}$ & $-0.00631^{b}$ & & & $-0.00531^{c}$ & $-0.00552^{\mathrm{a}}$ \\
\hline & & & $(0.00206)$ & $(0.00305)$ & & & $(0.00159)$ & $(0.00297)$ \\
\hline
\end{tabular}


Table 7 The determinants of the relative minimum wages, OLS (Continued)

\begin{tabular}{|c|c|c|c|c|c|c|c|c|}
\hline Province dummies & No & Yes & No & Yes & No & Yes & No & Yes \\
\hline N & 2033 & 2033 & 1862 & 1862 & 2033 & 2033 & 1862 & 1862 \\
\hline Adj. $R^{2}$ & 0.260 & 0.432 & 0.263 & 0.390 & 0.273 & 0.459 & 0.247 & 0.396 \\
\hline
\end{tabular}


Table 8 The determinants of the relative minimum wages in 2003 and 2009, OLS

\begin{tabular}{|c|c|c|c|c|c|c|c|c|}
\hline & \multicolumn{4}{|l|}{2003} & \multicolumn{4}{|l|}{2009} \\
\hline & $\overline{M a x}$ & Max & Min & Min & Max & Max & Min & Min \\
\hline & (1) & (2) & (3) & (4) & (5) & (6) & (7) & (8) \\
\hline \multirow[t]{2}{*}{ Ln(GDP per capita) } & -0.0000853 & $-0.00216^{\mathrm{b}}$ & -0.000730 & $-0.00257^{c}$ & $-0.00241^{b}$ & $-0.00374^{c}$ & $-0.00280^{c}$ & $-0.00368^{c}$ \\
\hline & $(0.00131)$ & $(0.00101)$ & $(0.000992)$ & $(0.000732)$ & $(0.000877)$ & $(0.000869)$ & $(0.000723)$ & $(0.000792)$ \\
\hline \multirow[t]{2}{*}{ Employment rate } & $-0.0242^{b}$ & $-0.0163^{b}$ & $-0.0224^{b}$ & $-0.0111^{a}$ & 0.00448 & 0.000359 & 0.00641 & 0.00170 \\
\hline & $(0.0104)$ & $(0.00744)$ & $(0.00847)$ & $(0.00561)$ & $(0.00517)$ & $(0.00615)$ & $(0.00518)$ & $(0.00531)$ \\
\hline \multirow[t]{2}{*}{ GDP growth rate } & -0.0109 & -0.00231 & -0.00476 & 0.00356 & 0.000781 & 0.00807 & 0.00361 & 0.00534 \\
\hline & $(0.0118)$ & $(0.00807)$ & $(0.0103)$ & $(0.00706)$ & $(0.00827)$ & $(0.00748)$ & $(0.00852)$ & $(0.00719)$ \\
\hline \multirow[t]{2}{*}{ Tertiary sector share } & -0.00402 & -0.00193 & -0.00290 & -0.00164 & -0.00279 & $-0.00529^{a}$ & -0.00296 & $-0.00583^{b}$ \\
\hline & $(0.00317)$ & $(0.00319)$ & $(0.00297)$ & $(0.00247)$ & $(0.00453)$ & $(0.00293)$ & $(0.00369)$ & $(0.00263)$ \\
\hline \multirow[t]{2}{*}{ Private employment share } & 0.00403 & 0.000513 & -0.000623 & $-0.00600^{\mathrm{b}}$ & $-0.00886^{c}$ & $-0.00528^{\mathrm{a}}$ & $-0.00493^{\mathrm{a}}$ & -0.00291 \\
\hline & $(0.00745)$ & $(0.00348)$ & $(0.00717)$ & $(0.00288)$ & $(0.00245)$ & $(0.00259)$ & $(0.00274)$ & $(0.00272)$ \\
\hline \multirow[t]{2}{*}{ FDI share in GDP } & 0.0223 & 0.0104 & 0.0162 & 0.0101 & 0.00870 & 0.00822 & -0.00162 & 0.00441 \\
\hline & $(0.0135)$ & $(0.00958)$ & $(0.0118)$ & $(0.00717)$ & $(0.0123)$ & $(0.0113)$ & $(0.0101)$ & $(0.00866)$ \\
\hline \multirow[t]{2}{*}{ Fiscal expenditure/GDP } & $-0.0260^{c}$ & $-0.0218^{c}$ & $-0.0123^{\mathrm{a}}$ & $-0.0140^{b}$ & -0.00689 & -0.00537 & -0.00301 & -0.00215 \\
\hline & $(0.00821)$ & $(0.00748)$ & $(0.00671)$ & $(0.00554)$ & $(0.00467)$ & $(0.00417)$ & $(0.00411)$ & $(0.00436)$ \\
\hline \multirow[t]{2}{*}{ Service sector/GDP } & 0.0935 & $0.0833^{\mathrm{a}}$ & 0.0534 & $0.0675^{\mathrm{a}}$ & $0.0998^{\mathrm{a}}$ & $0.106^{c}$ & 0.0595 & $0.0810^{b}$ \\
\hline & $(0.0574)$ & $(0.0415)$ & $(0.0433)$ & $(0.0336)$ & $(0.0516)$ & $(0.0358)$ & $(0.0471)$ & $(0.0331)$ \\
\hline \multirow[t]{2}{*}{ Per capita number of enterprises } & 0.000392 & $0.000558^{\mathrm{a}}$ & $0.000312^{\mathrm{a}}$ & $0.000602^{c}$ & $0.000330^{c}$ & $0.000270^{c}$ & $0.000295^{c}$ & $0.000272^{c}$ \\
\hline & $(0.000238)$ & $(0.000287)$ & $(0.000168)$ & $(0.000175)$ & $(0.0000752)$ & $(0.0000770)$ & $(0.0000761)$ & $(0.0000682)$ \\
\hline \multirow[t]{2}{*}{ Ln(consumption per capita)_rural } & -0.000874 & -0.000248 & 0.00172 & 0.00235 & $-0.00288^{b}$ & -0.00153 & -0.000929 & -0.000476 \\
\hline & $(0.00180)$ & $(0.00187)$ & $(0.00173)$ & $(0.00181)$ & $(0.00115)$ & $(0.00116)$ & $(0.00129)$ & $(0.00129)$ \\
\hline \multirow[t]{2}{*}{ Ln(consumption per capita)_urban } & $-0.0125^{c}$ & $-0.0102^{b}$ & $-0.0104^{c}$ & $-0.0123^{c}$ & -0.00152 & 0.000929 & -0.00160 & -0.000933 \\
\hline & $(0.00336)$ & $(0.00381)$ & $(0.00313)$ & $(0.00299)$ & $(0.00175)$ & $(0.00240)$ & $(0.00202)$ & $(0.00212)$ \\
\hline
\end{tabular}


Table 8 The determinants of the relative minimum wages in 2003 and 2009, OLS (Continued)

\begin{tabular}{|c|c|c|c|c|c|c|c|c|}
\hline Province dummies & No & Yes & No & Yes & No & Yes & No & Yes \\
\hline N & 240 & 240 & 240 & 240 & 258 & 258 & 258 & 258 \\
\hline Adj. $R^{2}$ & 0.251 & 0.488 & 0.234 & 0.529 & 0.135 & 0.450 & 0.095 & 0.401 \\
\hline
\end{tabular}


It is interesting to see whether the timing of the minimum-wage adjustment is related to regional characteristics and more importantly to minimum-wage levels. Two alternative stories can be told.

The first is the race-to-the-bottom story. The local officials compete in GDP growth performance to gain better chances of promotions. If they believe that higher minimum wage drove up labor costs, deterred potential investors, and eventually harmed growth, they have incentives to set minimum-wage levels lower than competing regions. A province that adjusts its minimum wage later would choose lower levels than a similar province that adjusts the minimum wage earlier. The second story, which we heard of often in conversation with officials and scholars, is the keep-up-with-the-Joneses one. Local officials do not want to have minimum wages lower than competing provinces, for several reasons, justified or unjustified. First, higher minimum wage is itself an indicator of better economic performance, which might be valued in official promotions. Second, while seeming unfriendly to employer, it may help a region attract quality workers, which seems to be truly believed by some local officials. ${ }^{4}$ If the keep-up-withthe-Joneses hypothesis is true, provinces adjusting their minimum wages later should choose higher minimum wages.

In both theories, announcing the new minimum-wage policy later allows the local government to observe the new policy of other local governments. Therefore, we hypothesize that the local government tends to adjust the minimum-wage policy later, which leads to the procrastination of the minimum-wage adjustment within a year. ${ }^{5}$

Table 9 reports the number of provinces that implement new minimum wages in each month from 1995 to 2007. There is a considerable variation in the time chosen for new minimum wages, and also the variation changed from 1995 to 2007. In earlier years, most local governments chose January and July, the starting point of a year or the half year. From around 2003, more provinces choose the last two quarters in a natural year to implement their new minimum wages. A regression of the month of adjustment on a year gives a coefficient of 0.25 , and the standard error is 0.04 . This might be due to the fact that local governments compete on minimum-wage levels and waiting allows them to observe the action of other provinces.

Table 9 Month when new minimum wage was implemented

\begin{tabular}{llllllllllllll}
\hline & 1995 & 1996 & 1997 & 1998 & 1999 & 2000 & 2001 & 2002 & 2003 & 2004 & 2005 & 2006 & 2007 \\
\hline January & 12 & 7 & 8 & 8 & 4 & 4 & 3 & 5 & 6 & 6 & 5 & 1 & 3 \\
February & 1 & 1 & 0 & 0 & 0 & 0 & 0 & 0 & 0 & 1 & 1 & 0 & 0 \\
March & 0 & 0 & 1 & 1 & 1 & 3 & 4 & 3 & 3 & 0 & 1 & 2 & 1 \\
April & 2 & 2 & 1 & 1 & 0 & 0 & 1 & 2 & 0 & 0 & 0 & 1 & 1 \\
May & 4 & 5 & 4 & 3 & 3 & 2 & 3 & 3 & 1 & 3 & 2 & 3 & 2 \\
June & 1 & 1 & 1 & 0 & 0 & 0 & 0 & 0 & 0 & 0 & 0 & 0 & 0 \\
July & 7 & 10 & 9 & 11 & 15 & 15 & 14 & 11 & 11 & 10 & 10 & 7 & 5 \\
August & 0 & 0 & 0 & 0 & 0 & 0 & 0 & 0 & 0 & 0 & 0 & 2 & 2 \\
September & 0 & 2 & 4 & 4 & 4 & 2 & 0 & 2 & 3 & 2 & 3 & 6 & 4 \\
October & 1 & 1 & 2 & 2 & 3 & 3 & 4 & 4 & 6 & 8 & 6 & 7 \\
November & 0 & 0 & 0 & 0 & 0 & 0 & 0 & 0 & 0 & 1 & 2 & 1 \\
December & 0 & 0 & 0 & 0 & 0 & 1 & 1 & 1 & 1 & 0 & 1 & 1 \\
Total & 28 & 29 & 30 & 30 & 30 & 30 & 30 & 31 & 31 & 31 & 31 & 31 \\
\hline
\end{tabular}


Is there any relationship between the month of minimum-wage adjustment and minimum-wage levels? ${ }^{6}$ Announcing the minimum wage later allows the local government to observe the behavior of its peer local governments. If the race-to-the-bottom story dominates, the local government would like to set a lower minimum wage than its competitors. On the other hand, if the keep-up-with-the-Joneses story dominates, local governments will set a higher minimum wage than their competitors. Which story dominates in reality is subject to empirical test.

Table 10 provides a rigorous empirical study, where we regress the level of minimum wages on the month of minimum-wage adjustment and a set of other control variables. These control variables are important as they allow us to compare regions with similar economic development levels. In the first row, we use the highest level of minimum wage within a city as the dependent variable. The results suggest that regions adjusting their minimum wages later tend to have slightly higher minimum wages. In the second row, we use the natural log of the highest minimum wage within a city as the dependent variable. Again, the coefficients on the month of minimum-wage adjustment are significantly positive but small in magnitude, none of them greater than $1 \%$. In panel $C$, we use the relative minimum wage (the ratio of the highest minimum wage within a city to the average wage of the city) as the dependent variable, and we get similar results. Using the lowest minimum wage within a city (panels D to E) produces similar results.

These results indicate that local governments want to keep up with the Joneses, but at the same time, they do not want to raise minimum wages too much higher than other provinces with the risk of damaging growth.

Table 10 Time adjusted and the level of minimum wages (coefficients on the month of adjustment)

\begin{tabular}{llll}
\hline & $(1)$ & $(2)$ & $(3)$ \\
\hline Dependent variable $=$ & & & \\
A: the highest level of mw within a city & $2.811^{\mathrm{a}}$ & $1.957^{\mathrm{a}}$ & 1.543 \\
& $(1.602)$ & $(1.106)$ & $(1.203)$ \\
B: Ln (the highest level of mw within a city) & $0.00761^{\mathrm{b}}$ & $0.00734^{c}$ & $0.00621^{\mathrm{b}}$ \\
& $(0.00323)$ & $(0.00258)$ & $(0.00291)$ \\
C: The highest level of mw within a city relative to average wage & 0.0000794 & $0.000218^{c}$ & $0.000224^{\mathrm{b}}$ \\
& $(0.0000767)$ & $(0.0000791)$ & $(0.0000890)$ \\
D: the lowest level of mw within a city & 1.187 & $1.952^{\mathrm{a}}$ & $1.712^{\mathrm{a}}$ \\
& $(1.751)$ & $(0.999)$ & $(0.996)$ \\
E: Ln(the lowest level of mw within a city) & 0.00431 & $0.00767^{c}$ & $0.00688^{\mathrm{b}}$ \\
& $(0.00428)$ & $(0.00249)$ & $(0.00279)$ \\
F: The lowest level of mw within a city relative to average wage & -0.00000654 & $0.000195^{c}$ & $0.000205^{\mathrm{b}}$ \\
& $(0.0000705)$ & $(0.0000699)$ & $(0.0000761)$ \\
Year dummies & Yes & Yes & Yes \\
Province dummies & No & Yes & No \\
City dummies & No & No & Yes \\
\hline
\end{tabular}

The controls that are not reported are the same as those in Table 8 . Standard errors in parentheses; ${ }^{a},{ }^{b}$, and ${ }^{c}$ represent significance levels of 10,5 , and $1 \%$, respectively 


\section{Discussions and conclusions}

The emerging literature on minimum-wage policy in China reflects a growing demand for redefining the labor relations in the Chinese labor market. Minimum-wage policies, along with unions, and collective bargaining are discussed of more often than ever in both academia and public policies. Although there are many studies showing the impact of China's minimum-wage policy on wages, employment, and inequality, large or small, significant or insignificant, expected or unexpected, results in this paper suggest that the significant increase in the minimum wage is mainly a reflection rather than a cause of the rapid growth of the Chinese economy.

China is a large country with economic development levels varying substantially across regions (Kanbur and Zhang 2005). It decentralizes the implementation of the minimum-wage policy, leading to a large regional variation in minimum wages. Our findings have a major implication in making predictions about the regional variation in minimum wages in the future. The basic pattern we observe is that the regional variation has been declining. A question then emerges: will the regional variation continue to decrease? The answer seems to be yes, for the following reasons. First, the simple extrapolation of the existing trend predicts fewer levels of minimum wages within a province and declining HL ratios both within a province and within the whole country. If we assume a linear trend in the number of the minimum wages within a province, the number will decrease to around 3 by 2020, and the HL ratio will decrease to around 1.2. Second, this prediction is supported by our regression results as well (see Table 2). For the HL ratio results in particular, the share of the tertiary sector in GDP is negatively correlated with the HL ratio, and the trade share and the rural-urban income gap (the latter not being significant for the periods 2000-2007) are positively correlated with the HL ratio. The most possible changing direction of these factors points to a decreased regional variation: the share of the tertiary sector will increase continuously, China will become less dependent on export to boost its economy, and the rural-urban income gap has shown a declining trend. All suggest a lower within-province HL ratio in the future.

What about the regional difference in the minimum wage for the whole country? Although the number of minimum-wage levels shows no consistent trend, the HL ratio, the Gini coefficient, and the coefficient of variation decrease significantly. This is consistent with the fact that the regional wage gaps for unskilled workers decreased in recent years. Whalley and Xing (2014) show that while the wage gaps across a province for skilled workers increased significantly between 2002 and 2007, those of the unskilled workers decreased. As the unskilled workers constitute a major part of the population targeted by the minimum-wage policy, the convergence of regional wages for them suggests a convergence in the minimum-wage levels across regions.

\section{Endnotes}

${ }^{1}$ Shenzhen, for example, http://www.cnr.cn/2004news/internal/200505310023.html

${ }^{2}$ We also calculate the standard deviation of the regional minimum wages. Because this measure depends on the level of minimum wages, it increases. Once we use the nature of minimum wages, the standard deviation also declines, which is consistent with the results we report in the paper. 
${ }^{3}$ In the end of 2004, the minimum wages applied in Guangzhou and Shenzhen were 684 and 610 RMB, respectively. The new minimum wage in Guangzhou is only applicable after December 1. It was 510 RMB before that date.

${ }^{4}$ Among the five reasons to raise minimum wage in 2008, local officials in Shenzhen point out that raising minimum wage will help them attract skilled workers (http:// sztqb.sznews.com/html/2008-06/03/content_199567.htm accessed on 2014-12-17).

${ }^{5}$ Although the new regulation in 2004 mandates the local government to adjust the minimum wages at least once in every 2 years, most of the provinces adjust the minimum wages once a year.

${ }^{6}$ This question was partly inspired by a conversation to a government official in Shenzhen. He said Shenzhen raised its minimum wage to 1600 Yuan/month in February 2013, which was overtaken by Shanghai in April. But the differential is only 20 Yuan, which is symbolic rather than substantive.

Competing interests

The IZA Journal of Labor \& Development is committed to the IZA Guiding Principles of Research Integrity. The authors declare that they have observed these principles.

\section{Acknowledgements}

The authors would like to thank and acknowledge the financial support of International Development Research Centre (IDRC), Canada.

Responsible editors: Haroon Bhorat, Ravi Kanbur and Li Shi

Received: 10 March 2015 Accepted: 28 January 2016

Published online: 28 April 2016

\section{References}

Bloch FE (1980) Political support for minimum wage legislation. J Lab Res 1:245-53

Bloch FE (1993) Political support for minimum wage legislation: 1989. J Lab Res 14:187-90

Card, David, and Alan B Krueger (1995) Myth and Measurement: The New Economics of the Minimum Wage. Princeton: Princeton University Press

Chi, Wei, Richard B. Freeman, and Hongbin Li (2012) Adjusting to really big changes: the labor market in China, 1989-2009. NBER Working Papers 17721

Fang, Tony and Carl Lin (2014) Minimum wages and employment transitions: longitudinal evidence from China. Working Paper

Flinn, Christopher J (2011), The minimum wage and labor market outcomes, MIT press

Guo, Ji, Jianwei Xu and Muyang Zhang (2013) Political tournament, land supply and housing price: evidence from Chinese cities. Working Paper

Harris JR, Todaro MP (1970) Migration, unemployment and development: a two-sector analysis. Am Econ Rev 60(1):126-142

Johnson CF (2002) The politics of minimum wage legislation in the Western United States: lessons in policy and power. J Econ Iss 36(2):331-337

Johnson, William R, and Browning, Edgar K, (1983) "The Distributional and Efficiency Effects of Increasing the Minimum Wage: A Simulation." American Economic Review, 73: 204-11.

Kanbur, Ravi, and Xiaobo Zhang (2005) Fifty years of regional inequality in China: a journey through central planning, reform, and openness. Review of Development Economics, Wiley Blackwell, vol. 9(1), pages 87-106, 02

Kau JB, Rubin PH (1978) Voting on minimum wages: a time-series analysis. J Polit Econ 86(2):337-42

Li H, Zhou L-a (2005) Political turnover and economic performance: the incentive role of personnel control in China. J Public Econ 89:1743-1762

Neumark, David, and William L. Wascher, (2008). Minimum Wages. The MIT Press, Cambridge, MA

Rani U, Belser P, Oelz M, Ranjbar S (2013) Minimum wage coverage and compliance in developing countries. Int Labour Rev 153(3-4):381-410

Seltzer AJ (1995) The political economy of the Fair Labor Standards Act of 1938. J Polit Econ 103:1302-42

Silberman Jl, Durden GC (1976) Determining legislative preferences on the minimum wage: an economic approach. J Polit Econ 84(April 1976):317-29

Sobel RS (1999) Theory and evidence on the political economy of the minimum wage. J Polit Econ 107(4):761-785

Stigler GJ (1946) The economics of minimum wage legislation. Am Econ Rev 36(3):358-365

Whalley J, Xing C (2014) The regional distribution of the skill premia in urban China and its implications for growth and inequality. Int Labour Rev 153(3):395-420

Xing C, Li S (2012) Residual wage inequality in urban China, 1995-2007. China Econ Rev 23(2):205-222

Yang, Juan, and Morley Gunderson (2014) The impact of minimum wages on migrant workers' wages. Working Paper 